\title{
DE
}

OPEN

DOI: $10.1515 /$ jolace-2017-0021

\section{Teaching foreign language to adults from the aspects of psychodidactic conception of education}

\author{
Gabriela Petrová \& Nina Kozárová \\ Constantine the Philosopher University in Nitra, Slovakia \\ gpetrova@ukf.sk \& nina.kozarova@ukf.sk
}

\begin{abstract}
Psychodidactic themes focused on the educational context have recently been resolved in both theoretical and research work. These themes are connected with general didactics, educational psychology, individual subject didactics, linguistics, philosophy, anthropology and neurosciences. Since the psychodidactic context of education is a widespectral and interdisciplinary topic, the present contribution deals with the issues of psychological aspects in the context of foreign language learning of adults.

Good lecturers are looking for ways to help participants develop key competences. The support of lecturers has a chance to be successful especially when it is systematic and includes high-quality theoretical preparation. The aim of this paper is to attract attention, to a theoretical level, to using psychodidactic aspects during foreign language training of adults as well as to the building of competences necessary for the self- realisation of training course participants.
\end{abstract}

Key words: psychodidactics, education of adults, knowledge, structuring, constructivism, structuring tasks.

\section{Introduction}

How do people learn? How is it possible that we can remember the lyrics of songs but cannot recall the titles of famous authors' works? How do we remember information? How can we optimize and make the methods of learning more effective?

Currently the psychodidactic streams of individual subject didactics try to ascertain answers for these and similar questions. The psychodidactic perception of teaching and learning could actually be characterized as a leading concept of constructivist didactics. Psychodidactics offers various insights into the teaching process and its subsequent questions, which up to the present have not been answered. It is important that the lecturer understands the mechanisms of learning, is able to identify and work with the learning styles of his/her clients as well as be able to properly structure the curriculum ... The themes which belong to 
the core of psychodidactic interests have not yet been touched upon. For this reason the next text pays closer attention to the psychodidactic dimension of education along with the focus on selected psychodidactic areas.

\section{Psychodidactics}

In the process of finding ways to make teaching and learning more effective answers can be found within the psychodidactic understanding of education. The term psychodidactics was first used in 1951 by Aebli (former student of Piaget) who explained the term as a way to make pedagogy more scientific by connecting and blending the psychological theory of thinking development and pedagogy.

For the needs of the present paper the opinion of Duchovičová (2011, p. 337338 ) is included. She claims: "Psychodidactics focuses attention on metacognitive processes - the understanding of learning processes and learning situations triggered by a teacher, by a programme or by a text which altogether work as a means not as the aim. This led to the breakdown of isolated didactic modeling of universal teaching schemes regardless of the specific context and subject didactics." We understand the primary focus of psychodidactics on education through which psychological knowledge is implemented.

International as well as domestic political power structures gradually search for various means of education which would meet the needs of the European democratic future. The function of a lecturer continually changes due to individual didactic concepts. He/she is not an absolute guarantor of truth but a facilitator who makes the construction of new knowledge easier for clients; therefore, the lecturer should apply in practice such procedures that will develop determinants of modern education among learners. Until the present the term psychodidactics has not been completely obvious although within the pedagogical and psychological professional community it has gradually established its place. Psychodidactic aspects perceive a lecturer as a mediator of a client's knowledge while placing particular emphasis on his/her personality, the development of cognitive, personal and learning characteristics.

There is no doubt that learning is a lifelong process through which an individual acquires knowledge, perceives an uncountable amount of information, creates a set of values and shapes its own behaviour. Each human being learns in his/her specific way, someone fancies memorization without the search for deeper connections, another one needs to understand the essence of a thing - its core.

As stated by Mužík (2012, p. 23): "Lifelong learning represents a fundamental change of understanding the whole of education. The traditional formalized school system makes up only the basis for education; it is just part of it. In contemporary society a human being should be provided with the opportunity to become further educated at various stages of its development, to realize a variety of transitions between education, learning and employment. This is about ensuring access to 
education throughout one's entire life, ensuring opportunities for learning to the level of personal possibilities and limits."

Within the process of lifelong education psychodidactics is in fact the key area, as it encourages independent thinking and allows one to see problems in depth from different perspectives.

\section{The psychodidactic concept of education}

In the case of adaptation towards educational needs the overall change in the nature of teaching is supported so that new and active teaching strategies would be used and disseminated. In this regard various forms of cross-subject integration are convenient, and enable the development of key competencies.

Then the main course in education becomes the principle: learn to cognize and experience. In the light of this approach difficult tasks stand before the lecturer as well as before the client: to master the methods involving how to teach/learn, how to use new information and communication technologies, to learn how to interact, to be able to work independently.

The psychological dictionary defines thusly: "Psychodidactics - a discipline that deals with the psychological questions of education: its development is based on expanding and deepening knowledge of the cognitive psychology of the last decade and is partly the result of the development of telematics, cooperative learning and similar approaches of the psychology of learning."

Psychodidactics as a theory of the teaching and the psychology of learning is embedded in explanation of educational processes from a psychological point of view. According to our opinion its task is to elaborate new topics of cognitive psychology that would contribute to effective transfer and acquisition of educational information and processes in educational reality.

In the development of scientific knowledge about the field of psychological theories of learning we come across various theories - which reflect different approaches to understanding of mechanisms for the acquisition of knowledge, skills and habits. The most significant theories are behaviouristic, humanistic, cognitive (constructivism) and social interactionist theory. Their basic assumptions and principles with focus on foreign language learning are discussed in detail in the following literature (Brown, 1994; Williams \& Burden, 1997; and others).

Contemporary preferred learning strategies for adults are in our public space expressed as a policy of lifelong learning and education of the highest number of people possible. An important aspect in addressing the many challenges of the $21^{\text {st }}$ century seems rightfully to be the use of the educational potential of adults. The desire to learn is necessary in order to implement this process into the modern mature lifestyle - because it is a part of the lifelong learning concept in which 
education and continuous lifelong learning represent a very important area of social and economic life.

As stated by Mužik (2012, p. 23): "Education is an institutionalized activity aimed at gaining information, knowledge, skills, habits or professional competences. Education cannot be understood only as a means for obtaining the qualification for profession (job position, function). Its aim is mainly personal growth and development, integration into society via the passing on of the cultural and social heritage, sharing certain social values and shaping of a human being by self-awareness, responsibility and realization of human rights."

Within the psychodidactic concept of education the focus is aimed at the way the lecturer presents the subject matter to the clients and their subsequent mental representations which are mostly varied. It is important that first the lecturer understands the content that should be interpreted to the learners - to create a structure. This may simplify the mediation of the content while individual specificities of each learner cannot be ignored. After all it is about the mediation of curriculum with the assistance of suitable strategies that the cognitive level of a client would be developed to the maximum possible extent.

Each human being constructs his/her knowledge system by selection, modification, comparison and organization of information. This system includes social interaction, information, life skills and experience. The psychodidactic concept of education pays increased attention to the teaching styles of the lecturer and learning styles of the clients and at the same time questions individual kinds of intelligence and their use in teaching which are to be addressed. The attempt of such a concept of education is to promote autonomous pedagogical thinking, evaluation of individual didactic concepts by which the base on which a teacher makes didactic decisions becomes wider. The lecturer as a mediator of the learner's knowledge should always and foremost encourage the development of independent thinking of clients. In the modern understanding of learning it is not acceptable that clients would only be passive receivers of content/knowledge. Participation in the learning process by the learner awakens new memory capacity, develops intellect and all sides of the learner's personality It positively motivates him/her towards education.

The psychodidactic concept of education encourages the lecturer to link theory with practice and supports the development of generally applicable skills and knowledge.

\section{Constructivism}

The changes in the concepts of education have always transformed in response to the changes in society. Nowadays the education of adults can be labelled as the most significant trend in the field of education. Constructivism constitutes one of the epistemological backgrounds of teaching. During the interwar period appears 
one of the streams of cognitive-psychological theories, constructivism. Unlike the Swiss psychologist considered the father of constructivism, Piaget, who understood cognitive development "inside out" through maturation Vygotsky emphasized the influence of the environment. Further on he claimed that cognitive development proceeds through the internalisation of knowledge from context. The work of both authors influenced other professionals in this field of interest such as Gredler, Backelard, Larochelle, van der Brink, Giorfan, Garanderie and Novak.

According to the Dictionary of Pedagogy by Průcha, Walterová \& Mareš (2001, p.105), constructivism is characterized as: "a broad stream of theories in sciences which focus on behaviour and in social sciences. This stream emphasizes the active role of a subject and the importance of his/her internal preconditions for pedagogical and psychological processes as well as the importance of his/her interaction with the environment and society."

According to constructivist understanding learning is seen as a deeply individual process in which a human being constructs and interprets reality based on his/her personal experience. Constructivism as a part of educational policy tries to modify the internal knowledge system of a human - and as much as possible to lead the individual to use the current state of scientific knowledge. We agree with the opinion of Kosíková (2011) who indicates that in recent years constructivism belongs among the most influential trends in didactics. Constructivism can be considered as one way of thinking about cognition and constructivists try to overcome the transmission of traditional teaching.

The knowledge of all humans is based on a semantic network $\rightarrow$ a map that is formed by connecting already acquired concepts with new ones. The terms are therefore considered as the basic units of thinking. They can be of specific or abstract form and in this regard we also distinguish between general and specific terms/concepts.

According to the theory of didactic constructivism the fundamental principle of education is the activity of a learner. Constructivists reject the transfer of already known knowledge - content in its definitive form. Actually it is the opposite of the lecturer striving to have the clients understand the content. The understanding is present when a person constructs knowledge on his/her own. Learning for comprehension is the main "scope of the work" within constructivism. The point is that the client works with new pieces of information, compares them and transforms them in a way so that they make sense and the learner comprehends $\rightarrow$ understands them.

The lecturer should support the activity and experience of clients, he/she should require dialogue between them, cooperative learning, respect the attitudes of participants as well as their learning styles. According to authors Vyskočilová \& Dvořak (2002) learning in constructivist terms is based on mutual interaction 
between the individual learner and the new content. During this interaction an individual encodes and decodes data, acquires knowledge and searches for clues that ease the connection to other information.

\section{Constructivist procedure:}

a) by the application of constructivism in education when clients work on authentic activities the term is then understandable;

b) there is a gradual shift from preconception (unclear concept to further work with) to the essence of the term;

c) the so-called phase of knowledge breakthrough $=>$ discovery of the conceptual core (a set of typical characteristics, mental representation);

d) clarification of terminology or conceptual core $=>$ understanding of mutual interdependencies and relationships (conceptualization: acquisition of terms).

Ormrod (2003) offers a different view on constructivism as one of the approaches to the learning process. He understands it as a way in which the subject of learning builds thoughts, ideas, and concepts that are based on current as well as previous knowledge. Such building of knowledge runs through the active "work" of a learner, his/her own experience and effective operation with individual information. Throughout the work the lecturer should support the active participation of clients within the educational process as in this moment the client knows how to think independently, consider and solve problems through the application of knowledge. This results in comparison of previous information with new material and their subsequent inclusion into the knowledge system.

With respect to the principles of constructivism we are mainly talking about: reduction of large amounts of abstract subject content (in order not to gain empty verbalism so that the learner really understands what he/she is taught, what he/she says), reduction of factual elements of the curriculum, flexibility of educational contents, use of interdisciplinary connections (for easier remembering of complex information), putting emphasis on individual work with information by participants, elimination of misconceptions, respect of an individual client's characteristics and his/her own pace at work, removal of isolated knowledge, building of complex knowledge systems, modification of a learner's structures of internal knowledge systems, transfer of already acquired knowledge into practical life, a client's awareness of his/her own thought processes, leaving the option for a client to interpret his/her own internal knowledge systems.

\section{Psychodidactic aspects of language learning}

Languages are a key to mutual understanding in the world today and so it was in the past. They are the codes of social communication between individuals, social 
groups and whole nations. Languages can unite as well as separate. Within language are preserved the life and knowledge of major historical epochs; therefore, they are an invaluable source of knowledge regarding religions, literature but also political sciences from across the centuries or even millennia. With regard to the international context in the changed socio-political and economic conditions and with regard to expanding globalization and the entrance of Slovakia into the European Union the education policy is modified.

With growing demands for foreign language skills in all spheres of social life conditions and objectives of foreign language education have been largely changed while demands on the quality of language teaching have increased. In the field of foreign language education the change is mainly reflected in the adoption of the Common European Framework of Reference for teaching foreign languages. Nowadays it is clear that any approach to language learning cannot be seen as whole/unified without relying on psychology, primarily the psychology of learning and teaching. This particularly because of the dynamic relation between the processes of learning and teaching as the knowledge about learning procedures is the basis from which are drawn recommendations for teaching practice.

Learning of languages is a complicated issue mainly with a highlight on its interdisciplinary nature. The research and investigation of this issue is based on elementary sciences such as linguistics, pedagogy, psychology but lately also with increased emphasis on newly emerged interdisciplinary sectors such as psycholinguistics, sociolinguistics, neurolinguistics, cognitive linguistics, computer linguistics and others.

In linkage to development of theoretical knowledge of the fundamental sciences, generalisation of teaching experience as well as the demands of practice in the course of evolution have caused different approaches and methods of teaching foreign languages to appear constantly. This emergence takes place also because of the development of cognitive psychological theories of language learning which underline the importance of the process of information processing and creation of an internal representation of the target language.

In connection to the development of theoretical cognition within initial scientific disciplines and by the generalization of pedagogical experiences as well as by the requirements from the practice, various approaches and methods in foreign language teaching and learning have appeared throughout time. The development of cognitive and psychological theories about learning foreign languages has also contributed to this situation especially the importance of information processing and creation of an inner representation of the target language.

The teaching of foreign languages in Slovakia is accompanied by many problems. It is necessary to step into educational practice with methods that will 
be more effective and further develop the teaching of foreign languages by promotion of the communicative competence of people. From abroad new trends pervade, methods and approaches that try to effectively teach individuals a foreign language; however, nowadays we know that it is not sufficient to apply some sort of banal innovation, modification or change but rather it is necessary to discover why it is quite difficult to learn any foreign language - to find the causes of problems and seek solutions.

The causes may be a result of general trends in our educational system to overestimate the need for declarative knowledge instead of procedural, to emphasize mechanical memorization and the accumulation of encyclopaedic knowledge which possibly loads the client with facts and information without appropriate interconnection and without further developing the ability to apply this knowledge in a practical way in real life.

Despite the fact that scientific research of foreign language learning is a relatively new scientific area foreign literature has presented knowledge about the processes of foreign language acquisition; however, relatively few specialists have engaged in researching learning and the acquisition of a foreign language.

Today we know that the capacity of the human mind is influenced by many factors. The question about the capacity of human memory is full of contradictory opinions. As one of the reasons for the inconsistency seems to be the tendency to quantify the capacity of human memory in the traditional way of measurement. Psychodidactics therefore also focuses on the area of human memory improvement whether in relation to the recall of previously stored information or in relation to capacity.

We differentiate two approaches regarding how to achieve memory improvement:

1. Effective learning strategies with regard to individual characteristics of clients;

2. The arrangement of information which each learner has to acquire.

Nowadays there are no doubts about the need for humans to be able to communicate in a foreign language or in multiple languages both in written and spoken form. Today there is no exception - people of productive age must use a foreign language at work.

In the learning of foreign languages we also come across people in post productive age. Many organizations and third sector institutions have expanded their range of training programmes of foreign language courses by devoting these primarily to seniors. Significant differences of young people, mature adults and seniors in relation to foreign language learning cannot be neglected, particularly the differences in motivation, methodology and content of foreign language education. 
The ability to learn languages is based on a concept - communicative learning principle. A particular emphasis is placed on the meaning of each science as a spontaneous expression of intellectual activity, wish or reflection of a certain specific situation.

Surveys that focused on foreign language education (Krashen, Seliger, Hartnett, Stevick) showed that learners with the dominance of the left hemisphere prefer the deductive style of learning while learners with a focus on the right hemisphere were successful in an environment with an inductive teaching style.

The predominance of the left hemisphere leads to better acquisition of individual words and to the accumulation of linguistic specificities. Individuals can more easily work with abstraction, classify, organize and reorganize their knowledge. On the other hand the dominance of the right hemisphere in thinking leads to better management of the overall ideas, shaping concepts, generalization, metaphors and emotionally coloured terms. (Brown, 1987).

As stated by Škoda and Doulík (2011) the more complex a form of information is and the more senses involved while obtaining the information, the easier it is for the creation of an association bond and an individual remembers the information more easily. In educational practice however teachers are often confronted with a phenomenon in which new pieces of information can interfere with the processing of information within short term memory. If the lecturers during the class do not sufficiently repeat the old content and do not provide participants with time for the creation of association links of the old content with the new one, information is quickly forgotten. Moreover if teachers do not respect the need for repetition of the particulars it may cause a chaotic mixture of isolated rather than connected information.

If the client is involved in the structure of learning texts it becomes for him/her clearer and easier-to-remember, as the participants remember the content in which are all elements are logically arranged. When remembering content the visualization of discussed topics helps through a variety of pictures, graphs, schemes or mind map. This is due to the fact that while reading the human being uses the left hemisphere of the brain and while using visualization of individual elements the right brain hemisphere is active.

\section{Conclusion}

As it was indicated in the introduction of the contribution, psychodidactic context of education is an interdisciplinary wide spectrum topic because it is just psychodidactics that offers different views of the processes of learning and teaching. It is impossible to include all the psychodidactic aspects of education of the adults in a single contribution. Our effort was, on the theoretical level, to draw 
attention to the use of psychodidactic aspects of teaching the adults foreign languages.

Our priority was to focus first on the way the teacher uses to present and explain the subject matter, i.e. a foreign language, and then on the mantal representation of the thought subject by clients. Therefore, we have also paid attention to constructivism which forms one of the epistemological pillars of teaching. Learning from the constructivist aspects is understood as a process through witch everybody interprets themselves and constructs their reality.

It extremely important for clients not only to be passive observers of the teaching process but also active participants who are able to structure the acquired knowledge, understood it and use it in practice.

\section{References}

Brown, D. (1987). Principles of Language Learning and Teaching. NJ: Prentice-Hall. Brown, G., Malmkjaer, K., \& Williams, J. (1996). Performance and Competence in Second Language Acquisition. Cambridge University Press.

Brown, H. D. (1994). Principles of Language Learning and Teaching. Englewood Cliffs New Jersey: Prentice Hall Regent.

Duchovičová, J. (2011). Psychodidaktika. In Vybrané kapitoly z didaktiky pedagogiky a sociálnej pedagogiky (pp. 218 - 229). Nitra : PF UKF.

Kosíková, V. (2011). Psychologie ve vzdelávaní a její psychodidaktické aspekty. Praha: Grada.

Kosová, B. (2000). Rozvoj osobnosti žiaka (so zameraním na 1. stupeň základnej školy). Prešov: Rókus.

Mužík, J. (2012). Profesní vzdělávání dospělých. Praha: Wolters Kluwer.

Ormrod, J. E. (2003). Developing Learners. Educational Psychology: Fourth Edition.

Upper Saddle River, NJ : Merrill Prentice Hall.

Průcha, J., Walterová. E., \& Mareš. J. (2003). Pedagogický slovník. Praha: Portál.

Škoda, J. \& Doulík, P. (2011). Psychodidaktika. Praha: Grada Publishing.

Veteška, K. et al. (2009). Nové paradigma v kurikulu vzdělávaní dospělých. Praha : Educa Service.

Vyskočilová, E. \& Dvořák, P. (2002). Didaktika jako věda a jako nástroj poznávaní učitele. In Kalhous, Z., Obst, O. et al., Školní didaktika (pp. 17-61). Praha: Portál. Williams, M. \& Burden, R. L. (1997). Psychology for Language Teachers. Cambridge: University Press. 


\section{Contact}

Prof. PhDr. Gabriela Petrová, CSc.

Constantine the Philosopher University

Faculty of Education

Department of Education

Dražovská 4, 94974 Nitra, Slovakia

gpetrova@ukf.sk

PaedDr. Nina Kozárová

Constantine the Philosopher University

Faculty of Education

Department of Education

Dražovská 4, 94974 Nitra, Slovakia

nina.kozarova@ukf.sk 